\title{
PEER SEXUAL HARASSMENT AND COPING MECHANISMS OF FEMALE STUDENTS IN A NIGERIAN UNIVERSITY
}

\author{
Popoola, Bayode Isaiah \\ Department Of Educational Foundations \& Counselling, \\ Obafemi Awolowo University, \\ lle Ife, Nigeria \\ email: bayopope@oauife.edu.ng \\ bayodep@yahoo.com
}




\section{Abstract}

This study was designed to investigate the prevalence and nature of peer sexual harassment among female Nigerian university students. It also examined the perception of students about peer sexual harassment and ascertained the coping mechanisms adopted by victims of peer sexual harassment. Participants consisted of 387 female undergraduate students selected by convenience sampling from three Faculties at the Obafemi Awolowo University. A selfconstructed instrument with a test-retest reliability coefficient of 0.79 was administered on students to collect data on their experience and perception of peer sexual harassment as well as adopted coping strategies. The results of the study indicated that verbal harassment was the most frequent type of peer sexual harassment experienced by female students. Findings from the study also showed that most victims of peer sexual harassment did not report their harassment to authorities but adopted strategies that did not involve direct confrontation with their harassers.

The study concluded that there was the need for a virile counselling programme in all Nigerian universities to stem down the incidence of peer sexual harassment and that such a programme should be targeted not only at victims but also at perpetrators of sexual harassment.

Key Words: sexuality, sexual victimisation, sexual harassment, sexual oppression.

\section{Introduction}

The term sexual harassment has various definitions in research literature. Brandenburg (1983) defined it as any attempt to coerce an unwilling person into a sexual relationship, or to subject a person to unwanted sexual attention, or punish a refusal to comply. Seymour (1979) used the term to refer to the behaviour of 
individuals who use their power and position in an establishment to extort sexual favours or gratification from their subordinates. In the same vein, Denga and Denga (2004) defined it as the use of influence, position or power by a male to get a female to satisfy his sexual desires. Many other scholars (Benson and Thomson, 1982; Annette and Balthrope, 1982; Metha and Nigg, 1983; Onuma, 1984) viewed the phenomenon not only in terms of male-female exploitation of a power relationship but also in terms of power exploitation by any person in position of authority over another person who cannot refuse sexual demands without the risk of reprisal. Thus, sexual harassment can be conceptualised as a social construct that is deeply embedded in dimensions of power, gender and sexuality.

Within the school setting, sexual harassment is used to encompass a wide range of unwelcome sexually oriented and gender offensive behaviours that contribute to a hostile learning environment. Such behaviours can be conceptualised on a continuum ranging from fairly mild actions to extreme ones. According to Sandler (1981), harassment at its extreme may include subtle pressure for sexual activity, physical assault of a sexual nature and outright demand for sexual favours accompanied by implied or overt threats concerning one's grades. Behaviours such as unnecessary touching and pinching, sexist remarks, leering or ogling and verbal abuse were classified by Adamolekun (2003) as mild forms of sexual harassment in university campuses.

Defining sexual harassment within the school setting presents its specific problems (Paludi, 1997). Unlike in the workplace where sexual harassment usually involves sexual coercion or demands for sexual favours accompanied by workrelated sanctions for refusal, peer sexual harassment in schools might not necessarily entail sexual coercion or include sanctions for refusal; and the harasser might not have clear sexual intent in mind (Duncan, 1999; Gillander Gådin \& Hammarstrom, 2000). However, according to Witkowska (2005), some instances of peer harassment may carry a possibility of an implied coercion component based on 
popularity, or social status within the peer group. It could also apply to a situation in which a student is threatened with physical harm or having his or her reputation damaged, or is promised something desirable, such as popularity or becoming boyfriend/girlfriend, in return for compliance with inappropriate advances. In line with this conceptualisation, this study adopts AAUW's (2001) definition of sexual harassment as "unwanted and unwelcome sexual behaviour that interferes with the student's life".

Many Nigerian researchers (Owuamanam, 1990; Aba, 1992; Denga, 1996; Adamolekun, 2003) have produced empirical evidence to show that sexual harassment is a pervasive social problem in Nigerian university campuses, though most of these studies focused mainly on harassment of female students by male lecturers. In many parts of the world, research findings have shown that sexual harassment perpetrated by students is much more common than sexual harassment perpetrated by teachers. For instance, in a large-scale representative study in the United States, AAUWEF (1993) reported that $87 \%$ of girls and $71 \%$ of boys reported having been sexually harassed by another student. Another study by Lee, Croninger, Linn and Chen (1996) found that the rates of sexual harassment perpetrated by teachers were lower: $20 \%$ for girls and $8 \%$ for boys. Fineran and Bennett (1998) also found that sexual harassment in schools is widespread, and most experiences involve students harassing other students.

Peer sexual harassment in Nigerian universities has not received much attention from researchers and policy makers compared to teacher-student harassment. This may be attributed to the tendency among Nigerians to view peer sexual harassment as a normal part of college life, which every student must learn to tolerate. Also, there is widespread belief among the people that the moral implications as well as the social consequences of peer sexual harassment are not as serious as teacher-to-student harassment. However, a growing body of literature has now begun to accumulate to suggest that the consequences of peer sexual 
harassment are as debilitating as those from teacher-student harassment.

This study was designed to investigate the prevalence of peer sexual harassment as experienced by female undergraduates in a Nigerian university campus. The study was also to find out what female university students regard as peer sexual harassment as well as determine the strategies used by victims to cope with it. It was hypothesized that the marital status of female students would significantly influence their perception and experience of peer sexual harassment as well as their coping strategies.

\section{Method}

The target population for the study consisted of all undergraduate female students of the Obafemi Awolowo University, Ile Ife. Statistics from the University website indicated that there were about 12,000 female undergraduate students in the University at the time of this study. From this population 387 female participants were selected by convenience sampling from three randomly selected Faculties in the University. The participants consisted of 346 unmarried and 46 married female students. Seventy-one of them (18.3\%) were less than 16 years old; 132 $(34.1 \%)$ were within the $16-18$ years age bracket, $110(28.4 \%)$ were $19-21$ years old; while $74(19.1 \%)$ were above 21 years of age. The participants were approached by the researcher in various lecture rooms and their consent sought before the research instrument was administered on them.

The research instrument was a self-constructed questionnaire titled "Questionnaire on Sexual Harassment and Coping Strategies of University Students". The instrument has a test-retest reliability coefficient of 0.79 over an interval of two weeks. It is divided into three sections. Section A consists of an introduction containing a definition of peer sexual harassment. This section also seeks demographic information from participants such as age, marital status and level of study. Section B seeks respondents' 
opinions on behaviours they personally consider as peer sexual harassment in the University campus. The section contains eight common behaviours of students which respondents were required to classify as sexually harassing or not sexually harassing. Sections $C$ and D measure respondents' experiences of peer sexual harassment and coping strategies respectively. Data collected were subjected to frequency counts, simple percentages and chi-square statistical analysis.

\section{Results}

One of the major objectives of the study was to determine the kinds of behaviour considered sexually harassing by female undergraduate students. To do this, data collected on respondents' opinions on what constitute peer sexual harassment were subjected to descriptive statistics. The results are presented in Table 1.

The data in Table 1 indicate that three kinds of peer behaviour were considered by majority of respondents as sexually harassing. These were being physically assaulted for not accepting sexual advances (90.2\%); subtle pressure for sexual activity (80.4\%) and being threatened to enter into sexual relationship (92.8\%). On the other hand, majority of respondents were of the opinion that behaviours such as unnecessary touching $(67.7 \%)$, sexist remarks about one's body ( $80.4 \%)$, sexual bugging $(54.5 \%)$, verbal abuse of a sexual nature $(65.5 \%)$ and indecent sexual rumours $(51.7 \%)$ do not constitute peer sexual harassment. 
Table 1: Female students' opinion on what constitutes peer sexual harassment

\begin{tabular}{|l|l|c|c|c|c|}
\hline \multirow{2}{*}{ NO } & \multicolumn{1}{|c|}{ BEHAVIOUR } & \multicolumn{4}{|c|}{$\begin{array}{c}\text { PERCEPTION OF } \\
\text { BEHAVIOUR AS }\end{array}$} \\
\cline { 3 - 6 } & \multicolumn{1}{|c|}{$\begin{array}{l}\text { Sexual } \\
\text { Harassment }\end{array}$} & \multicolumn{2}{|c|}{$\begin{array}{c}\text { Not Sexual } \\
\text { Harassment }\end{array}$} \\
\cline { 3 - 6 } & $\begin{array}{l}\mathrm{N} \\
\text { Unnecessary touching of } \\
\text { one's body parts }\end{array}$ & 125 & 32.3 & $\mathrm{~N}$ & $\%$ \\
\hline 2 & $\begin{array}{l}\text { Sexist remarks about one's } \\
\text { body }\end{array}$ & 189 & 48.8 & 198 & 51.2 \\
\hline 3 & $\begin{array}{l}\text { Subtle pressure for sexual } \\
\text { activity }\end{array}$ & 311 & 80.4 & 76 & 19.6 \\
\hline 4 & $\begin{array}{l}\text { Sexual bugging on } \\
\text { walls/notice } \\
\text { boards/chalkboards }\end{array}$ & 176 & 45.5 & 211 & 54.5 \\
\hline 5 & $\begin{array}{l}\text { Being threatened to enter into } \\
\text { sexual relationship }\end{array}$ & 359 & 92.8 & 28 & 7.2 \\
\hline 6 & $\begin{array}{l}\text { Verbal abuse of a sexual } \\
\text { nature }\end{array}$ & 133 & 34.4 & 254 & 65.5 \\
\hline 7 & $\begin{array}{l}\text { Having indecent sexual } \\
\text { rumours spread about one }\end{array}$ & 187 & 48.3 & 200 & 51.7 \\
\hline 8 & $\begin{array}{l}\text { Physically assaulted for not } \\
\text { accepting sexual advances }\end{array}$ & 349 & 90.2 & 38 & 9.8 \\
\hline
\end{tabular}

Another major objective of the study was to ascertain the prevalence of peer sexual harassment as experienced by female students in the University. To this end, respondents were asked to indicate how frequently they had experienced some acts of harassment from colleagues within the current academic session. Their responses were subjected to descriptive statistical analysis as shown in Table 2. 
The data in Table 2 indicate that respondents experienced various forms of peer sexual harassment. The most common type of reported sexual harassment was verbal abuse of a sexual nature $(85.0 \%)$. This was followed by unnecessary touching $(81.1 \%)$, indecent sexual rumours $(80.3 \%)$, sexual bugging $(72.5 \%)$, threats to enter into sexual relationship (71.6\%) and subtle pressure for sexual activity (70.5\%). The data however indicate that physical assault for refusing sexual advances (18.1\%) was the least experienced form of peer sexual harassment. The conclusion arising from these results is that female students experienced a high prevalence of acts of sexual harassment from their mates in the University.

Table 2: Prevalence of Peer Sexual Harassment

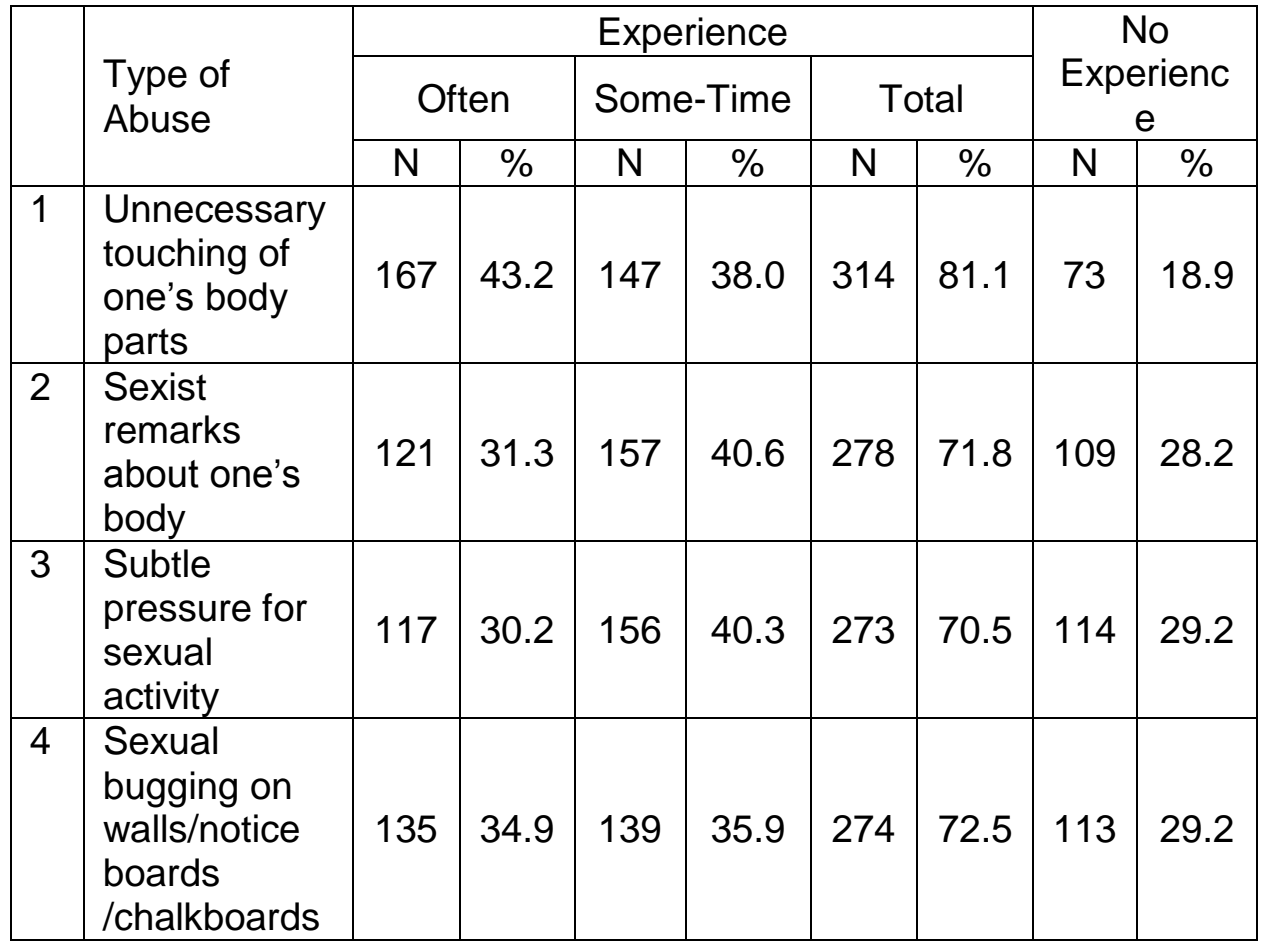




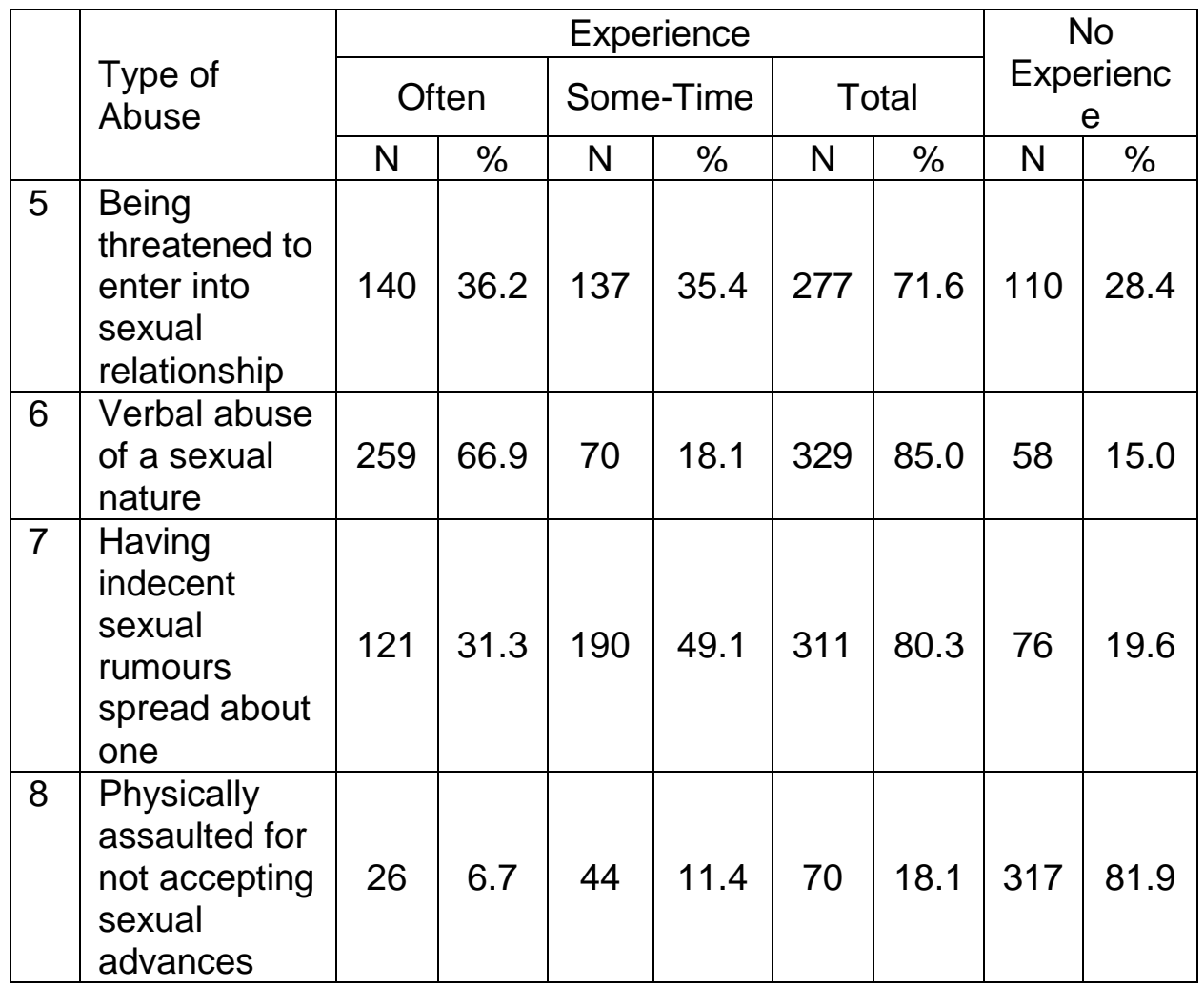

This study also investigated the coping strategies adopted by female students who were exposed to acts of peer sexual harassment. The results of the analysis on coping strategies used by respondents are presented in Table 3.

The data in Table 3 show the coping strategies adopted by victims of peer sexual harassment. The results indicate that avoiding the harasser was the most commonly used strategy against acts of sexual harassment such as unnecessary touching (47.5\%), verbal abuse of a sexual nature (72.3\%) and physical assault $(34.3 \%)$. Ignoring or enduring the harassment was the most common strategy adopted against acts such as sexist remarks 
(74.1\%), sexual bugging (58.4\%) and indecent sexual rumours $(44.7 \%)$. Confronting the harasser was used mainly as a coping strategy when the harassment involved spreading of sexual rumours against the victim. The results also showed resorting to prayers and lodging of official complaints to university authorities were coping strategies rarely employed by victims against any of the acts of peer sexual harassment investigated in the study.

Table 3: Coping Strategies Adopted by Victims of Peer Sexual Harassment

\begin{tabular}{|c|c|c|c|c|c|c|c|c|}
\hline & \multirow[b]{2}{*}{$\begin{array}{l}\text { Type of Peer } \\
\text { Sexual } \\
\text { Harassment }\end{array}$} & \multicolumn{7}{|c|}{ COPING STRATEGIES } \\
\hline & & 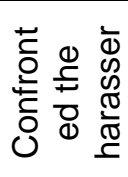 & 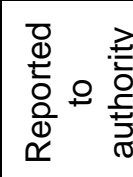 & 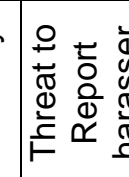 & 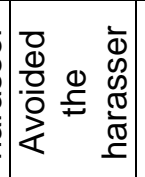 & 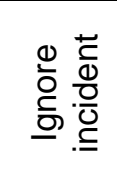 & 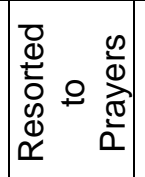 & 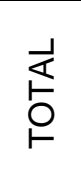 \\
\hline 1 & $\begin{array}{l}\text { Unnecessary } \\
\text { touching of } \\
\text { one's body } \\
\text { parts }\end{array}$ & $\begin{array}{c}42 \\
(13.4)\end{array}$ & $\begin{array}{c}7 \\
(2.2)\end{array}$ & $\begin{array}{c}24 \\
(7.6)\end{array}$ & $\begin{array}{c}149 \\
(47.5)\end{array}$ & $\begin{array}{c}87 \\
(27.7)\end{array}$ & $\begin{array}{c}5 \\
(1.6)\end{array}$ & 314 \\
\hline 2 & $\begin{array}{l}\text { Sexist } \\
\text { remarks about } \\
\text { one's body }\end{array}$ & $\begin{array}{c}33 \\
(11.9\}\end{array}$ & $\begin{array}{c}19 \\
(6.8)\end{array}$ & $\begin{array}{c}1 \\
(0.4)\end{array}$ & $\begin{array}{c}17 \\
(6.1)\end{array}$ & $\begin{array}{c}206 \\
(74.1)\end{array}$ & $\begin{array}{c}2 \\
(0.7)\end{array}$ & 278 \\
\hline 3 & $\begin{array}{l}\text { Subtle } \\
\text { pressure for } \\
\text { sexual activity }\end{array}$ & $\begin{array}{c}9 \\
(4.8)\end{array}$ & $\begin{array}{c}11 \\
(5.8)\end{array}$ & $\begin{array}{c}109 \\
(57.7)\end{array}$ & $\begin{array}{c}14 \\
(7.4)\end{array}$ & $\begin{array}{c}5 \\
(2.6)\end{array}$ & $\begin{array}{c}41 \\
(21.7)\end{array}$ & 189 \\
\hline 4 & $\begin{array}{l}\text { Sexual } \\
\text { bugging on } \\
\text { walls/notice } \\
\text { boards/chalkb } \\
\text { oards }\end{array}$ & - & $\begin{array}{c}5 \\
(1.8)\end{array}$ & $\begin{array}{c}23 \\
(8.4)\end{array}$ & $\begin{array}{c}67 \\
(24.5)\end{array}$ & $\begin{array}{c}160 \\
(58.4)\end{array}$ & $\begin{array}{c}19 \\
(6.9)\end{array}$ & 274 \\
\hline 5 & $\begin{array}{l}\text { Being } \\
\text { threatened to } \\
\text { enter into } \\
\text { sexual } \\
\text { relationship }\end{array}$ & $\begin{array}{c}22 \\
(7.9)\end{array}$ & $\begin{array}{c}47 \\
(17.0)\end{array}$ & $\begin{array}{c}182 \\
(65.7)\end{array}$ & $\begin{array}{c}13 \\
(4.7)\end{array}$ & $\begin{array}{c}6 \\
(2.2)\end{array}$ & $\begin{array}{c}7 \\
(2.5)\end{array}$ & 277 \\
\hline
\end{tabular}




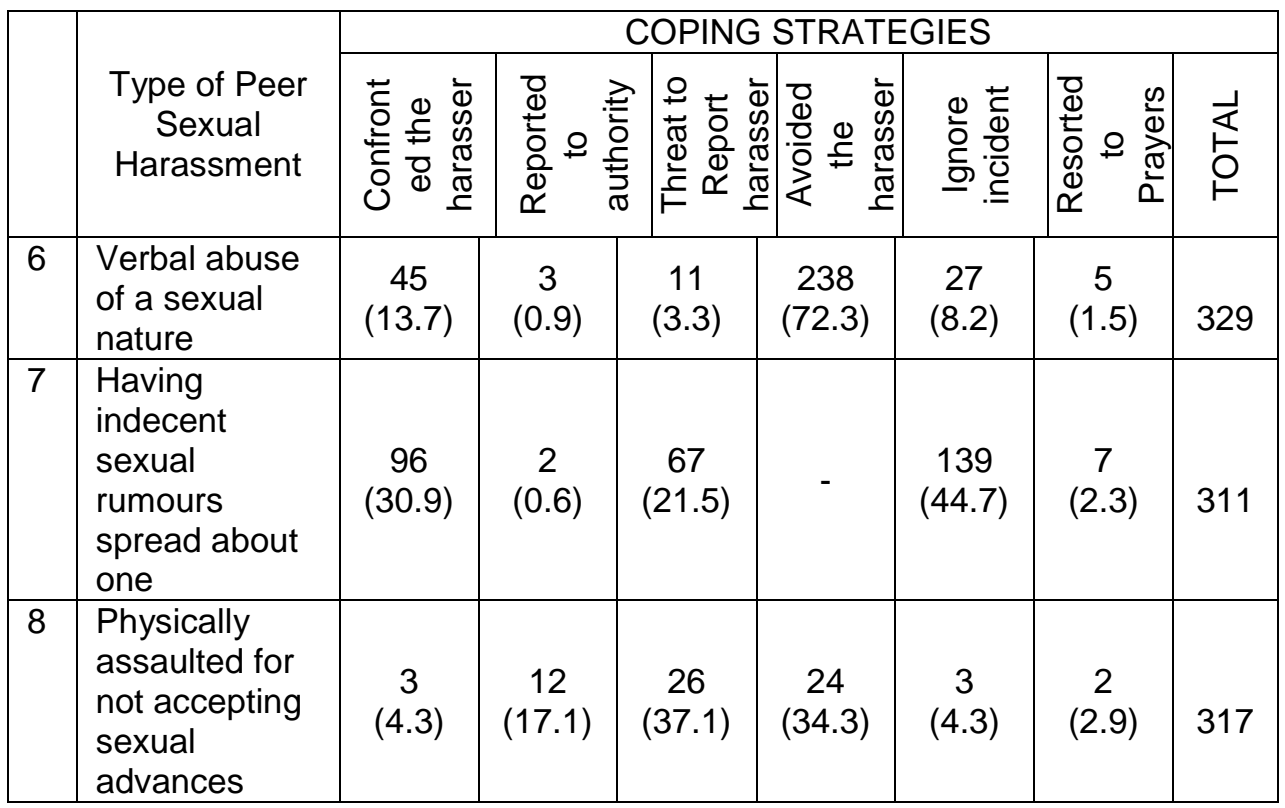

\section{${ }^{\star}$ Figures in brackets represent percentages}

A further attempt was made in the study to determine the influence of respondents' marital status on their perception, experience of peer sexual harassment as well as adopted coping strategies. It was hypothesized that marital status would not significantly influence each of these variables. In testing the hypothesis, data on respondents' perception and experience of peer sexual harassment and coping strategies were subjected to chisquare statistical analysis as shown in Table 4.

Table 4: Chi-Square Values of the relationship between marital status and female students' opinion, experience of and coping mechanisms against peer sexual harassment 


\begin{tabular}{|c|c|c|c|c|}
\hline No & Type of Harassment & $\begin{array}{c}\text { Marital } \\
\text { status \& } \\
\text { opinion on } \\
\text { peer sexual } \\
\text { harassment } \\
\left(\chi^{2}\right) \text { df }=1\end{array}$ & $\begin{array}{c}\text { Marital status } \\
\text { \& experience } \\
\text { of peer } \\
\text { sexual } \\
\text { harassment } \\
\left(\chi^{2}\right) \mathrm{df}=2\end{array}$ & $\begin{array}{c}\text { Marital } \\
\text { status and } \\
\text { adopted } \\
\text { coping } \\
\text { strategies } \\
\left(\chi^{2}\right) \text { df }=5\end{array}$ \\
\hline 1 & $\begin{array}{l}\text { Unnecessary touching } \\
\text { of one's body parts }\end{array}$ & 2.98 & 5.24 & 4.55 \\
\hline 2 & $\begin{array}{l}\text { Sexist remarks about } \\
\text { one's body }\end{array}$ & 0.23 & 1.58 & 4.62 \\
\hline 3 & $\begin{array}{l}\text { Subtle pressure for } \\
\text { sexual activity }\end{array}$ & 1.44 & 1.54 & 2.14 \\
\hline 4 & $\begin{array}{l}\text { Sexual bugging on } \\
\text { walls/notice } \\
\text { boards/chalkboards }\end{array}$ & 0.11 & 3.35 & 4.47 \\
\hline 5 & $\begin{array}{l}\text { Being threatened to } \\
\text { enter into sexual } \\
\text { relationship }\end{array}$ & $4.07^{*}$ & 0.99 & 7.65 \\
\hline 6 & $\begin{array}{l}\text { Verbal abuse of a } \\
\text { sexual nature }\end{array}$ & 0.16 & 3.86 & 4.14 \\
\hline 7 & $\begin{array}{l}\text { Having indecent sexual } \\
\text { rumours spread about } \\
\text { one }\end{array}$ & $4.53^{*}$ & 3.68 & 2.83 \\
\hline 8 & $\begin{array}{l}\text { Physically assaulted for } \\
\text { not accepting sexual } \\
\text { advances }\end{array}$ & 3.44 & 3.79 & 2.88 \\
\hline
\end{tabular}

* Significant at $p<0.05$.

The results of the chi-square statistical analysis presented in Table 4 reveal that respondents' marital status did not significantly influence any of the acts of peer sexual harassment experienced by respondents as well as the adopted coping strategies against any of the various acts of sexual harassment. This means that being married did not actually prevent female students from being sexually harassed by other students; and that the coping strategies employed 
by married and single female students against peer sexual harassment were not significantly different. However, the results indicate that female students' opinion on what constitutes peer sexual harassment as it relates to the spread of sexual rumours $\left(\chi^{2}\right.$ $=4.53 ; \mathrm{df}=1 ; \mathrm{p}<0.05)$ and being threatened to enter into sexual relationships $\left(\chi^{2}=4.07 ; \mathrm{df}=1 ; p<0.05\right)$ were significantly influenced by their marital status. More married female students compared with their single counterparts tended to consider spreading of sexual rumours and being threatened to engage in sexual relationships as constituting acts of peer sexual harassment.

\section{Discussion}

The results of this study have shown that majority of female students in the University experience a high prevalence of acts of sexual harassment from their mates with verbal abuse of a sexual nature as the most prevalent form of harassment. The results also showed that being married did not shield university female students from being sexually harassed by their mates. These results are consistent with findings from earlier studies by Adamolekun (2003). The high rate of peer sexual harassment reported here should be a matter of serious concern to educational administrators considering that peer sexual harassment can have both short and long term psychological effects on its victims.

The findings of the study on the prevalence of peer sexual harassment suggest that public attention should henceforth be focused not only on teacher-student sexual harassment in Nigerian institutions but also on student-student sexual harassment. Traditionally, public attention has focused primarily on sexual harassment perpetuated by university teachers against their female students with little attention to peer sexual harassment. This study therefore brings into focus the need to recognize peer sexual harassment among university students as a pervasive social problem which requires urgent intervention of all stakeholders in tertiary education in Nigeria. 
The results of the study indicate that three kinds of peer behaviour were considered by majority of respondents as sexually harassing. These were physical assault, being threatened to enter into sexual relationship and subtle pressure for sexual activity. Other forms of behaviour such as sexual bugging, unnecessary touching and sexist remarks were considered by respondents as too mild to constitute sexual harassment. This result is therefore consistent with findings from an earlier study by Denga and Denga (2004). The researchers found that the Nigerian students' views of what constitutes sexual harassment differ from the western view simply in terms of strictness and cultural mores which make Nigerians regard behaviours like subtle pressure and sexist remarks about a woman's body irrelevant to sexual harassment. The respondents' perception of sexual harassment might therefore be a reflection of the general attitude of most Nigerians to issues relating to the sexual rights of individuals.

The findings of the study on the coping strategies adopted by victims of peer sexual harassment indicate that avoiding the harasser was the most commonly used strategy against acts of sexual harassment such as unnecessary touching, verbal abuse of a sexual nature and physical assault. Ignoring or enduring the harassment was also commonly used against acts such as sexist remarks, sexual bugging and indecent sexual rumours. It appears from these results that university female students exposed to peer sexual harassment preferred coping strategies which do not involve official actions or which might lead to direct confrontation with their harassers. The reason for this might not be unconnected with the absence of clear-cut definitions or procedures for channelling grievances about sexual abuse in many Nigerian university campuses. Also, many female students might not want to take official actions against their harassers either because of the fear of retaliation by the harassers or because they were afraid of the reporting procedure itself. According to Denga and Denga (2004), the advent of cultism on university campuses seems to have exacerbated sexual harassment in Nigeria as female students would 
rather prefer to endure the ordeal of peer sexual harassment than risk the retaliatory actions of sexual harassers, who most of the time, are members of campus cults.

\section{Implication for Practice}

This study has shown that peer sexual harassment exists with a disturbing frequency among Nigerian university students. In view of the negative consequences of this phenomenon on its victims, concerted efforts are required to address it. Universities authorities should establish effective grievance procedures that victims of sexual harassment can rely on to bring perpetrators to book. University authorities should prescribe clearly defined official sanctions against sexual harassers. This will definitely reduce the incidents of peer sexual harassment in the campuses thereby minimizing the physical, psychological and emotional pains experienced by students who are sexually harassed by their peers.

Counselling interventions are required to provide psychological support for victims of sexual harassment. Students who perpetrate sexual harassment should also be assisted by counsellors to change their behaviours and live harmoniously with others in the campuses.

\section{References}

AAUW. (2001). Hostile hallways: bullying, teasing, and sexual harassment in school. Washington: American Association of University Women.

Aba, C. (1992). Sexual assaults on students. London: Harper and Row.

Adamolekun, O. (2003). Papers on counselling and social work. Ibadan: College Press and Publishers Ltd.

American Association of University Women Educational Foundation. (1993). Hostile hallways: The AALJW survey on sexual harassment in America's schools. Washington, DC: Author. 
Annette, G. and Balthrope, R.B. (1982). Sexual harassment in work places and its ramifications for academic. College Student Personnel, $158-162$.

Benson, D. and Thomson, G. (1982). Sexual harassment on a university campus: The confluence of authority relations, sexual interest and gender stratification. Social Problems, 29, $236-251$.

Brandenburg, J.B. (1982). Sexual harassment in the university: Guidelines for establishing a grievance procedure. Journal of Women in Culture and Society, 8, 320 - 326.

Dahinten, V.S. (2003). Peer sexual harassment in adolescence: the function of gender. Canadian Journal of Nursing Research,35(2):56-73.

Denga, D.I. (1996). Counselling among adolescents. Lagos: Erit Egwa Press.

Denga, D.I. and Denga, H. (2004). Sexual harassment: A student's view point from a Nigerian university. The African Symposium, 4 (1).

Duncan, N. (1999). Sexual bullying. London: Routledge.

Fineran, S., \& Bennett, L. (1999). Gender and power issues of peer sexual harassment among teenagers. Journal of Interpersonal Violence, 14 (6), 626-641.

Gillander Gådin, K., \& Hammarstrom, A. (2000). 'We won't let them keep us quiet....' Gendered strategies in the negotiation of power: Implications for pupils' health and school health promotion". Health Promotion International, 15(4), 303-311

Lee, V. E., Croninger, R. G., Linn, E., \& Chen, X. (1996). The culture of sexual harassment in secondary schools. American Educational Research Journal, 2, 383-417.

Metha, A. and Nigg, J. (1983). Sexual harassment on campus: An institutional response. Journal of the National Association for Women Deans, Administrators and Counsellors, 46, 9-15.

Onuma, E. (1984). Against and in defence of lecherous lecturers. National Concord, April 30, p.3. 
Owuamanam, D.O. (1990). Strategies adopted by female students against sexual harassment in a university campus.

Paludi, M. A. (1997). Sexual harassment in schools. In W. O'Donohue (Ed.), Sexual Harassment: Theory, research, and treatment. Needham Heights: Allyn \& Bacon.

Sandler, B.R. (1981). Sexual harassment: A hidden problem. Educational Record, 62, 52 - 57.

Seymour, W.C. (1979). Sexual harassment. New York: Harper and Row.

Witkowska, E. (2005). Sexual harassment in schools Prevalence, structure and perceptions. Stockholm: National Institute for Working Life. 